\title{
Metabolic Syndrome in Aging Heart: Molecular Insights
}

Julieta Díaz-Juárez ${ }^{1}$, Gustavo Pastelín ${ }^{1}$ and Jorge Suarez ${ }^{2^{*}}$

${ }^{1}$ Department of Pharmacology, Instituto Nacional de Cardiología Ignacio Chávez, Ciudad de México, México

${ }^{2}$ Department of Medicine, University of California, San Diego, USA

"Corresponding author: Jorge Suarez, Department of Medicine, University of California, San Diego, USA, Tel: (858) 534-9931; Fax: (858) 534-9932; E-mail: jsuarez@ucsd.edu

Received date: July 27, 2017; Accepted date: August 04, 2017; Published date: August 12, 2017

Copyright: ( 2017 Diaz-Juarez J, et al. This is an open-access article distributed under the terms of the creative commons attribution license, which permits unrestricted use, distribution, and reproduction in any medium, provided the original author and source are credited.

\section{Abstract}

Risk factors that define the metabolic syndrome (MetS) develop with age increasing its prevalence. Therefore, MetS can be considered an age-related health problem. Mechanism involved in aging and MetS are incompletely understood. The goal of this review is to highlight novel molecular maladaptive mechanism that tiger cardiac disease and common in aging and MetS. We focus on mitochondrial energetic function as well as mitochondrial calcium handling. In addition, we analyzed the role of $\mathrm{O}-$ GlcNAcylation which is a posttranslational modification that triggers multiple signaling pathways.

Keywords: Aging; Heart; Metabolic syndrome; Molecular mechanisms; Mitochondrial calcium; O-GlcNAcylation

\section{Introduction}

Metabolic syndrome (MetS) is an arrangement of cardiovascular and metabolic risk factors that dramatically increase cardiovascular mortality and morbidity and type 2 diabetes [1-3]. MetS is a growing public health problem worldwide. The magnitude of the prevalence of MetS also signals to the complexity of the problem.

MetS is characterized by central obesity, dyslipidemia, compromised fasting glucose, and hypertension [4]. However, the pathophysiologic mechanisms that lead to MetS are incompletely understood.

The prevalence of MetS increases with age with cardiovascular disease being the most frequent outcome. Therefore, MetS can be considered an age-related disease.

Only after decades of intense research efforts worldwide we have identified important molecular targets of the aging process that lead to cardiovascular disease. We only describe some novel discoveries at the molecular level that revealed new therapeutic targets that have not been investigated.

\section{Aging and decreased cardiac function}

The process of general aging-related changes in model organisms has been explored recently [5-7]. The rate of aging is a controlled process governed by epigenetic pathways and biochemical processes which are conserved in evolution [6]. Aging is generally characterized by progressively impaired organ function and an increased propensity to death. This process indeed occurs in the heart. Of special relevance is that aging causes dysregulation of nutrient sensing, with abnormal metabolism and mitochondrial (Mito) dysfunction [5-7]. Though some studies have suggested that Reactive Oxygen Species (ROS) production may be implicated in the aging process, the role of ROS as a primary cause of cellular senescence has also been questioned $[6,8]$. Beyond these general concepts, it is clear that humans older than 65 years have an increased propensity for heart failure (HF) (e.g. 11/1000 persons) and that HF is enhanced further with increased age (e.g. $43 / 1000$ in humans $>80$ years old) $[9,10]$. MetS further worsen these data. This is relevant since HF is always associated with recurrent hospitalization, decreased quality of life and a reduction in life span [11].

\section{Alterations contributing to aging-related decreases in cardiac and Mito energetic function}

The heart is a highly active metabolic organ which is very rich in Mito [12] and therefore susceptible to decreased Mito energetic function. Several converging mechanisms contribute to decreased Mito function with aging, including decreased Mito biogenesis, decreased Mito quality and decreased energetic function of Mito normalized for Mito quantity $[6,13,14]$. Some reports find no significant changes [14] and others find decreases in the function of specific Mito complexes and increased ROS production $[13,15]$.

\section{Mito $\mathrm{Ca}^{2+}$ handling, $\left[\mathrm{Ca}^{2+}\right] \mathrm{m}$ and Mito energetic function}

Mito free calcium concentration $\left(\left[\mathrm{Ca}^{2+}\right] \mathrm{m}\right)$ is an important signaling mechanism for Mito energetic activity by enhancing the activity of oxidative phosphorylation, especially complex III, and the Vmax of Complex V [16]. In addition, several dehydrogenases in the Mito matrix are activated by $\left[\mathrm{Ca}^{2+}\right] \mathrm{m}$ including the Pyruvate Dehydrogenase Complex (PDC) which is the key enzyme for glucose oxidation (GOX) [17]. There are limited findings reported regarding aging-related changes in substrate consumption. A positron emissionbased approach was used to show that myocardial glucose utilization could be stimulated by dobutamine, only in youn, but not old hearts [18]. Without an adequate compensatory increase in glucose utilization and GOX, a decrease in high-energy phosphate generation will prevail in the aging heart.

$\left[\mathrm{Ca}^{2+}\right] \mathrm{m}$ is controlled by a complex set of mechanisms influencing Mito matrix $\mathrm{Ca}^{2+}$ uptake and release which have been reviewed $[19,20]$. Briefly, the outer Mito membrane (OMM) is quite $\mathrm{Ca}^{2+}$ permeable [21], but import across the inner Mito membrane (IMM) is highly regulated. The most important contributor to $\mathrm{Mito}^{\mathrm{Ca}^{2+}}$ uptake 
is the mitochondrial calcium uniporter complex (MCUC) with the MCU serving as a highly selective channel that moves $\mathrm{Ca}^{2+}$ ions across the IMM dependent on Mito membrane potential $(\Delta \Psi \mathrm{m})$. Recently, integrative genomics methods enabled the discovery of the molecular nature of MCU, and its regulatory subunits, MCUb, MICU1 and 2, and EMRE [22-27]. MCU is an integral membrane protein with two transmembrane domains that forms the pore through which Mito $\mathrm{Ca}^{2+}$ currents are conducted across the IMM [22,23]. MCUb has been identified as a member of the oligmeric pore complex which reduces Mito channel activity [26]. MICU1 contains EF-hand $\mathrm{Ca}^{2+}$-binding domains and is found in the Mito inter-membrane space (IMS), where it serves as a $\mathrm{Ca}^{2+}$-sensing gatekeeper, keeping the channel closed when $\mathrm{Ca}^{2+}$ levels are low and allowing the channel to open in response to transient $\mathrm{Ca}^{2+}$ rises [28-30]. In addition MICU1 contributes to optimal coupling between cytosolic $\mathrm{Ca}^{2+}$ transients and activation of Mito-based $\mathrm{Ca}^{2+}$-responsive dehydrogenases [28]. EMRE is a $10 \mathrm{kDa}$ protein proposed to be essential for the in vivo uniporter current and additionally bridges the Ca2+-sensing role of MICU1 and MICU2 with the $\mathrm{Ca}^{2+}$-conducting role of $\mathrm{MCU}$ [27].

Mito $\mathrm{Ca}^{2+}$ export is mediated by the Mito $\mathrm{Na}^{+} / \mathrm{Ca}^{2+}$ Exchanger (mNCX) and the Mito $\mathrm{H}^{+} / \mathrm{Ca}^{2+}$ Exchanger (mHCX) which have also been recently identified [31,32]. Short term opening of the Mito Permeability Transition Pore (MPTP) can also contribute to Mito $\mathrm{Ca}^{2+}$ release [33].

During the systolic and diastolic phase of a heartbeat, intermyofibrillar Mito (IFM) which are in close proximity to the sarcoplasmic reticulum (SR), are exposed to the changing levels of the cytosolic $\mathrm{Ca}^{2+}$ transient. The cardiac myocyte cytosolic calcium concentration $\left(\left[\mathrm{Ca}^{2+}\right] \mathrm{I}\right)$ increases from about $100 \mathrm{nM}$ during diastole, to about $500 \mathrm{nM}$ in systole; however in the privileged micro-domain between the ryanodine receptor (RyR2) of the SR and the IFM, $\left[\mathrm{Ca}^{2+}\right] \mathrm{I}$ transiently rises to $10-20 \mu \mathrm{M}$ during the systolic release phase of $\mathrm{Ca}^{2+}$ exiting the SR through the RyR2. Due to the relatively low affinity of MCU for $\mathrm{Ca}^{2+}$ the 20 to 40 fold higher $\left[\mathrm{Ca}^{2+}\right] \mathrm{I}$ levels, which persist for about $10 \mathrm{~ms}$ during systole, are the most active time for Mito $\mathrm{Ca}^{2+}$ import by the MCUC [34]. The Mito $\mathrm{Ca}^{2+}$ transient follows the cytosolic $\mathrm{Ca}^{2+}$ transient with a slight delay, and a much smaller magnitude. Overall the Mito $\mathrm{Ca}^{2+}$ uptake accounts only for $1-2 \%$ of cytosolic $\mathrm{Ca}^{2+}$ extrusion [35,36]. The impact of Mito $\mathrm{Ca}^{2+}$ handling is therefore not so much linked to its contribution the cytosolic $\mathrm{Ca}^{2+}$ transients, but derives more from the importance of $\left[\mathrm{Ca}^{2+}\right] \mathrm{m}$ for Mito energetic function. The amount of $\mathrm{Ca}^{2+}$ that enters Mito via MCU or other mechanisms, must be extruded to an equal extent by Mito $\mathrm{Ca}^{2+}$ exporters like the mNCX [31]. Feedback loops exist that regulate increased Mito import and resultant increased $\mathrm{Ca}^{2+}$ release, so, as to potentially protect Mito against $\mathrm{Ca}^{2+}$ overload [37]. Excessive $\left[\mathrm{Ca}^{2+}\right] \mathrm{m}$ loading, as can occur with an acute ischemic event, can result in the opening of the MPTP complex with large amounts of $\mathrm{Ca}^{2+}$ released into the cytoplasm, ultimately leading to activation of cardiac myocyte death pathways [38].

Studies in mice with ubiquitous or CM-specific inducible deletions of MCU have generated interesting findings. Mice with a ubiquitous knock-out of MCU are viable and show decreased energetic efficiency and maximal performance of skeletal muscle [39]. Cardiac function was not evaluated in detail. Subsequent work with MCU KO mice generated in a C57BL/6 background showed mid-gestation lethality [40]. Recent reports indicate that $\beta$-adrenergic responsiveness [41] and the fight or flight response, is dependent on MCU activity [42]. Two recent reports using mice with conditional cardiac myocyte-specific deletion of $\mathrm{MCU}[43,44]$ found that $\mathrm{MCU} \mathrm{Ca}{ }^{2+}$ conductance activity matches energetic supply with cardiac workload during an acute stress mediated by $\beta$ adrenergic stimulation [44]. It should be noted that the control mice and the mice with MCU deletion are in a normal "unstressed" physiological state, unless submitted to $\beta$ adrenergic stimulation or a sprint exercise $[43,44]$. Old mice are known to be submitted to aging-related "stresses" including decreasing cardiac function and have difficulty responding to an increased demand for cardiac work [45]. This may lead to post-translational modifications of MCU or of other MCUC members impairing Mito $\mathrm{Ca}^{2+}$ conductance functions independent of acute $\beta$ adrenergic stimulation. Other work has shown that post-translational modification of MCU by phosphorylation markedly enhances the $\mathrm{Ca}^{2+}$ conductance of MCU [46]. Using Tg mice with expression of a dominant negative form of MCU, no acute $\beta$ adrenergic stimulus was needed for MCU to function as Mito $\mathrm{Ca}^{2+}$ importer [47]. A new report demonstrated that simulated hyperglycemia in cardiac myocytes reduces $\left[\mathrm{Ca}^{2+}\right] \mathrm{m}$, and glucose oxidation with an increase in fatty acid oxidation [18]. Furthermore. Diaz-Juarez et al. demonstrated in the same report that restoring $[\mathrm{Ca} 2+] \mathrm{m}$ concentration to normal levels by genetically expressing MCU normalized glucose and fatty acid metabolism in spite of simulated hyperglycemia. These findings point out a possible pathophysiological role of MCUC in simulated ischemia.

\section{Excessive O-GlcNAcylation of CM and Mito proteins and Mito energetic function}

O-GlcNAcylation of serine or threonine residues of nuclear, cytoplasmic and Mito proteins is a dynamic and ubiquitous protein modification [48-50]. This process has emerged as a key regulator of critical biological functions including transcription and translational processes [51], and of Mito function [52], as was also shown by prior work [53]. Post-translational protein modifications by phosphorylation (O-P) and O-GlcNAc can have reciprocal effects on protein function and are mediated by different types of dynamic interplays. In addition, competitive and alternate modification of adjacent sites occurs as well as other interactions [49]. Overall modification of protein function by $\mathrm{O}-\mathrm{GlcNAc}$ derives from the interplay between protein modification by $\mathrm{O}-\mathrm{P}$ and $\mathrm{O}-\mathrm{GlcNAc}$.

The O-GlcNAc status of proteins is regulated by O-GlcNAc transferase (OGT) and O-GlcNAcase (GCA), which catalyze the addition and removal of O-GlcaNAc residues, respectively [54-58]. The overall catalytic activity of OGT is positively controlled by the concentration of its donor substrate UDP-GlcNAc, making it an excellent metabolic sensor. OGT is O-GlcNAcylated and tyrosinephosphorylated $[49,56]$. Recent evidence indicates that a shorter GCA splice variant, which has enzyme activity, occurs [59] and can be Mitodirected. Recently, several Mito proteins of the respiratory chain complex that undergo O-GlcNAcylation in the diabetic heart have been identified [53]. Interestingly, increased O-GlcNAcylation of cardiac proteins occurs in the aging heart [60].

\section{Conclusions}

It is currently unclear if the decrease in Mito energetic and metabolic function that occurs in the aging heart can be restored. Research is needed to explore this by using two novel interventions: 1) Rectifying $\left[\mathrm{Ca}^{2+}\right] \mathrm{m}$ through normalizing MCU levels and MCUC function, and 2) Reversing the excessive O-GlcNAcylation of cardiac myocytes and especially Mito proteins, including MCU. Currently no 
data are available in the literature for Mito $\mathrm{Ca}^{2+}$ handling, $\left[\mathrm{Ca}^{2+}\right] \mathrm{m}$ or MCUC levels in cardiac myocytes from aging heart. Increased OGlcNAcylation of cardiac myocyte proteins from aging heart has been reported [60], but no attempt has been made to reverse the excessive Mito protein O-GlcNAcylation of aging heart and determine if this can improve cardiac function in aging heart. Assuming that these questions can be answered, innovative therapeutic approaches for the declining function of the aging heart and its increased propensity to develop heart failure may result.

\section{Funding}

This Manuscript was supported by Grant from UC-MEXUS CONACYT (CN 15-1489).

\section{References}

1. Dekker JM, Girman C, Rhodes T, Nijpels G, Stehouwer CD, et al. (2005) Metabolic syndrome and 10-year cardiovascular disease risk in the Hoorn Study. Circulation 112: 666-673.

2. Galassi A, Reynolds K, He J (2006) Metabolic syndrome and risk of cardiovascular disease: a meta-analysis. Am J Med 119: 812-819.

3. Isomaa B, Almgren P, Tuomi T, Forsén B, Lahti K, et al. (2001) Cardiovascular morbidity and mortality associated with the metabolic syndrome. Diabetes Care 24: 683-689.

4. Tziomalos K, Athyros VG, Karagiannis A, Mikhailidis DP (2010) Endothelial dysfunction in metabolic syndrome: Prevalence, pathogenesis and management. Nutr Metab Cardiovasc Dis 20: 140-146.

5. Gems D, Partridge L (2013) Genetics of longevity in model organisms: debates and paradigm shifts. Annu Rev Physiol 75: 621-644.

6. López-Otín C, Blasco MA, Partridge L, Serrano M, Kroemer G (2013) The hallmarks of aging. Cell 153: 1194-1217.

7. Quarles EK, Dai DF, Tocchi A, Basisty N, Gitari L, et al. (2015) Quality control systems in cardiac aging. Ageing Res Rev 23: 101-115.

8. Ziegler DV, Wiley CD and Velarde MC (2015) Mitochondrial effectors of cellular senescence: beyond the free radical theory of aging. Aging Cell 14:1-7.

9. Curtis LH, Whellan DJ, Hammill BG, Hernandez AF, Anstrom KJ, et al. (2008) Incidence and prevalence of heart failure in elderly persons, 1994-2003. Arch Intern Med 168: 418-424.

10. Roger VL, Go AS, Lloyd-Jones DM, Benjamin EJ, Berry JD, et al. (2012) Heart disease and stroke statistics--2012 update: a report from the American Heart Association. Circulation 125: e2-e220.

11. Solomon SD, Anavekar N, Skali H, McMurray JJ, Swedberg K, et al. (2005) Influence of ejection fraction on cardiovascular outcomes in a broad spectrum of heart failure patients. Circulation 112: 3738-3744.

12. Page E, McCallister LP (1973) Quantitative electron microscopic description of heart muscle cells. Application to normal, hypertrophied and thyroxin-stimulated hearts. Am J Cardiol 31: 172-181.

13. Das KC, Muniyappa H (2013) Age-dependent mitochondrial energy dynamics in the mice heart: role of superoxide dismutase-2. Exp Gerontol 48: 947-959.

14. Davies SM, Poljak A, Duncan MW, Smythe GA and Murphy MP (2001) Measurements of protein carbonyls, ortho- and meta-tyrosine and oxidative phosphorylation complex activity in mitochondria from young and old rats. Free Radic Biol Med 31: 181-190.

15. Kumaran S, Subathra M, Balu M, and Panneerselvam C (2004) Ageassociated decreased activities of mitochondrial electron transport chain complexes in heart and skeletal muscle: role of L-carnitine. Chem Biol Interact 148: 11-18.

16. Glancy B, Balaban RS (2012) Role of mitochondrial Ca2+ in the regulation of cellular energetics. Biochemistry 51: 2959-2973.

17. Denton RM (2009) Regulation of mitochondrial dehydrogenases by calcium ions. Biochim Biophys Acta 1787: 1309-1316.
18. Soto PF, Herrero P, Kates AM, Dence CS, Ehsani AA, et al. (2003) Impact of aging on myocardial metabolic response to dobutamine. Am J Physiol Heart Circ Physiol 285: H2158-2164.

19. Gunter TE, Pfeiffer DR (1990) Mechanisms by which mitochondria transport calcium. Am J Physiol 258: C755-786.

20. Rizzuto R, Pinton P, Carrington W, Fay FS, Fogarty KE, et al. (1998) Close contacts with the endoplasmic reticulum as determinants of mitochondrial Ca2+ responses. Science 280: 1763-1766.

21. Santo-Domingo J, Demaurex N (2010) Calcium uptake mechanisms of mitochondria. Biochim Biophys Acta 1797: 907-912.

22. Baughman JM, Perocchi F, Girgis HS, Plovanich M, Belcher-Timme CA, et al. (2011) Integrative genomics identifies MCU as an essential component of the mitochondrial calcium uniporter. Nature 476: 341-345.

23. De Stefani D, Raffaello A, Teardo E, Szabo I and Rizzuto R (2011) A fortykilodalton protein of the inner membrane is the mitochondrial calcium uniporter. Nature 476: 336-340.

24. Perocchi F, Gohil VM, Girgis HS, Bao XR, McCombs JE, et al. (2010) MICU1 encodes a mitochondrial EF hand protein required for $\mathrm{Ca}\left({ }^{2}\right)$ uptake. Nature 467: 291-296.

25. Plovanich M, Bogorad RL, Sancak Y, Kamer KJ, Strittmatter L, et al. (2013) MICU2, a paralog of MICU1, resides within the mitochondrial uniporter complex to regulate calcium handling. PLoS One 8: e55785.

26. Raffaello A, De Stefani D, Sabbadin D, Teardo E, Merli G, et al. (2013) The mitochondrial calcium uniporter is a multimer that can include a dominant-negative pore-forming subunit. EMBO J 32: 2362-2376.

27. Sancak Y, Markhard AL, Kitami T, Kovacs-Bogdan E, Kamer KJ, et al. (2013) EMRE is an essential component of the mitochondrial calcium uniporter complex. Science 342: 1379-1382.

28. Csordás G, Golenár T, Seifert EL, Kamer KJ, Sancak Y, et al. (2013) MICU1 controls both the threshold and cooperative activation of the mitochondrial $\mathrm{Ca}^{2}$ uniporter. Cell Metab 17: 976-987.

29. Dorn GW 2nd, Maack C (2013) SR and mitochondria: calcium cross-talk between kissing cousins. J Mol Cell Cardiol 55: 42-49.

30. Drago I, Pizzo P, Pozzan T (2011) After half a century mitochondrial calcium in- and efflux machineries reveal themselves. EMBO J 30: 4119-4125.

31. Palty R, Silverman WF, Hershfinkel M, Caporale T, Sensi SL, et al. (2010) NCLX is an essential component of mitochondrial Na/Ca ${ }^{2}$ exchange. Proc Natl Acad Sci USA 107: 436-441.

32. Rottenberg H, Marbach M (1990) The Na (+)-independent Ca2+ efflux system in mitochondria is a $\mathrm{Ca} 2+/ 2 \mathrm{H}+$ exchange system. EBS Lett 274 : 65-68.

33. Bernardi P, von Stockum S (2012) The permeability transition pore as a $\mathrm{Ca}(2+)$ release channel: new answers to an old question. Cell Calcium 52: 22-27.

34. Williams GS, Boyman L, Chikando AC, Khairallah RJ, Lederer WJ (2013) Mitochondrial calcium uptake. Proc Natl Acad Sci USA 110: 10479-10486.

35. Andrienko TN, Picht E and Bers DM (2009) Mitochondrial free calcium regulation during sarcoplasmic reticulum calcium release in rat cardiac myocytes. J Mol Cell Cardiol 46: 1027-1036.

36. Bassani JW, Qi M, Samarel AM, Bers DM (1994) Contractile arrest increases sarcoplasmic reticulum calcium uptake and SERCA2 gene expression in cultured neonatal rat heart cells. Circ Res 74: 991-997.

37. Drago I, De Stefani D, Rizzuto R, Pozzan T (2012) Mitochondrial Ca2+ uptake contributes to buffering cytoplasmic $\mathrm{Ca} 2+$ peaks in cardiomyocytes. Proc Natl Acad Sci USA 109: 12986-12991.

38. Morciano G, Giorgi C, Bonora, M, Punzetti S, Pavasini R, et al. (2015) Molecular identity of the mitochondrial permeability transition pore and its role in ischemia-reperfusion injury. J Mol Cell Cardiol 78: 142-153.

39. Pan X, Liu J, Nguyen T, Liu C, Sun J, et al. (2013) The physiological role of mitochondrial calcium revealed by mice lacking the mitochondrial calcium uniporter. Nat Cell Biol 15: 1464-1472. 
Citation: Díaz-Juárez J, Pastelín G, Suarez J (2017) Metabolic Syndrome in Aging Heart: Molecular Insights. J Metabolic Synd 6: 230. doi: 10.4172/2167-0943.1000230

Page 4 of 4

40. Murphy E, Pan X, Nguyen T, Liu J, Holmström KM, et al. (2014) Unresolved questions from the analysis of mice lacking MCU expression. Biochem Biophys Res Commun 449: 384-385.

41. Fernandez-Sada E, Silva-Platas C, Villegas CA, Rivero SL, Willis BC, et al. (2014) Cardiac responses to beta-adrenoceptor stimulation is partly dependent on mitochondrial calcium uniporter activity. Br J Pharmacol 171: 4207-4221

42. Wu Y, Rasmussen TP, Koval OM, Joiner ML, Hall DD, et al. (2015) The mitochondrial uniporter controls fight or flight heart rate increases. Nat Commun 6: 6081.

43. Kwong JQ, Lu X, Correll RN, Schwanekamp JA, Vagnozzi RJ, et al. (2015) The Mitochondrial Calcium Uniporter Selectively Matches Metabolic Output to Acute Contractile Stress in the Heart. Cell Rep 12: 15-22.

44. Luongo TS, Lambert JP, Yuan A, Zhang X, Gross P, et al. (2015) The Mitochondrial Calcium Uniporter Matches Energetic Supply with Cardiac Workload during Stress and Modulates Permeability Transition. Cell Rep 12: 23-34.

45. Shioi T, Inuzuka Y (2012) Aging as a substrate of heart failure. See comment in PubMed Commons below J Cardiol 60: 423-428.

46. Jin OU, Jhun BS, Xu S, Hurst S, Raffaello A, et al. (2014) Adrenergic signaling regulates mitochondrial $\mathrm{Ca} 2+$ uptake through Pyk2-dependent tyrosine phosphorylation of the mitochondrial $\mathrm{Ca} 2+$ uniporter. Antioxid Redox Signal 21: 863-879.

47. Rasmussen TP, Wu Y, Joiner ML, Koval OM, Wilson NR, et al. (2015) Inhibition of MCU forces extramitochondrial adaptations governing physiological and pathological stress responses in heart. Proc Natl Acad Sci USA 112: 9129-9134.

48. Fulop N, Marchase RB, Chatham JC (2007) Role of protein O-linked Nacetyl-glucosamine in mediating cell function and survival in the cardiovascular system. Cardiovasc Res 73: 288-297.

49. Hart GW, Housley MP, Slawson C (2007) Cycling of O-linked beta-Nacetylglucosamine on nucleocytoplasmic proteins. See comment in PubMed Commons below Nature 446: 1017-1022.

50. Chatham JC and Marchase RB (2010) The role of protein O-linked beta$\mathrm{N}$-acetylglucosamine in mediating cardiac stress responses. Biochim Biophys Acta 1800: 57-66.
51. Butkinaree C, Park K, Hart GW (2010) O-linked beta-Nacetylglucosamine (O-GlcNAc): Extensive crosstalk with phosphorylation to regulate signaling and transcription in response to nutrients and stress. Biochim Biophys Acta 1800: 96-106.

52. Banerjee PS, Ma J, Hart GW (2015) Diabetes-associated dysregulation of O-GlcNAcylation in rat cardiac mitochondria. Proc Natl Acad Sci USA 112: 6050-6055.

53. Hu Y, Suarez J, Fricovsky E, Wang H, Scott BT, et al. (2009) Increased enzymatic O-GlcNAcylation of mitochondrial proteins impairs mitochondrial function in cardiac myocytes exposed to high glucose. J Biol Chem 284: 547-555.

54. Braidman I, Carroll M, Dance N, Robinson D, Poenaru L, et al. (1974) Characterisation of human $\mathrm{N}$-acetyl-beta-hexosaminidase C. FEBS Lett 41: 181-184.

55. Gao Y, Wells L, Comer FI, Parker GJ, Hart GW (2001) Dynamic Oglycosylation of nuclear and cytosolic proteins: cloning and characterization of a neutral, cytosolic beta- $\mathrm{N}$-acetylglucosaminidase from human brain. J Biol Chem 276: 9838-9845.

56. Kreppel LK, Blomberg MA, Hart GW (1997) Dynamic glycosylation of nuclear and cytosolic proteins. Cloning and characterization of a unique O-GlcNAc transferase with multiple tetratricopeptide repeats. J Biol Chem 272: 9308-9315.

57. Lubas WA, Frank DW, Krause M, Hanover JA (1997) O-Linked GlcNAc transferase is a conserved nucleocytoplasmic protein containing tetratricopeptide repeats. J Biol Chem 272, 9316-9324.

58. O'Donnell N, Zachara NE, Hart GW, Marth JD (2004) Ogt-dependent Xchromosome-linked protein glycosylation is a requisite modification in somatic cell function and embryo viability. Mol Cell Biol 24: 1680-1690.

59. Kim EJ, Kang DO, Love DC, Hanover JA (2006) Enzymatic characterization of O-GlcNAcase isoforms using a fluorogenic GlcNAc substrate. Carbohydr Res 341: 971-982.

60. Fulop N, Feng W, Xing D, He K, Not LG, et al. (2008) Aging leads to increased levels of protein $\mathrm{O}$-linked $\mathrm{N}$-acetylglucosamine in heart, aorta, brain and skeletal muscle in Brown-Norway rats. Biogerontology 9: 139-151. 